Pontifícia Universidade Católica $_{\text {mano }}$

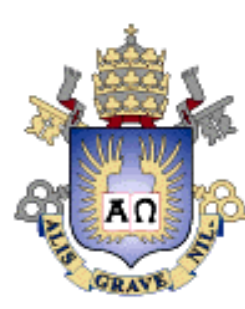

Antonio José Afonso da Costa

Justificação e Batismo na obra de Wolfhart Pannenberg;

Perspectivas para o diálogo ecumênico

Tese de Doutorado

Tese apresentada ao Programa de Pós-Graduação em Teologia Sistemático-Pastoral da PUC-Rio como requisito parcial para obtenção do título de Doutor em Teologia.

Orientador: Prof. Mario de França Miranda

Rio de Janeiro, fevereiro de 2007 


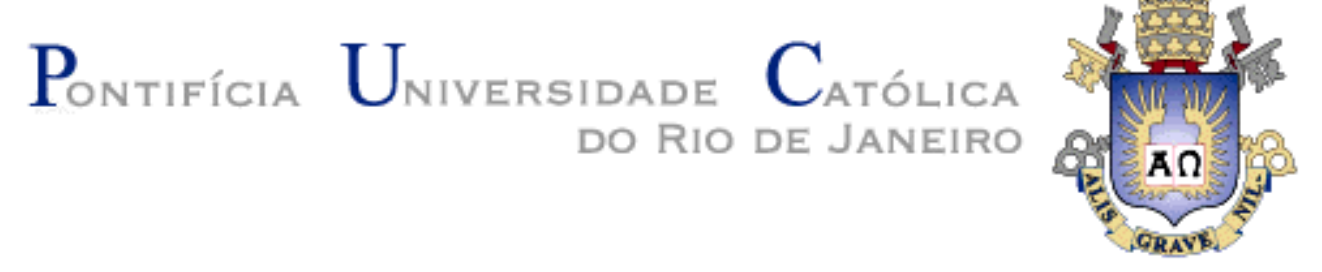

Antonio José Afonso da Costa

\title{
Justificação e Batismo na obra de Wolfhart Pannenberg \\ Perspectivas para o diálogo ecumênico
}

\begin{abstract}
Tese apresentada como requisito parcial para obtenção do grau de Doutor pelo Programa de PósGraduação em Teologia do Departamento de Teologia do Centro de TEOLOGIA E Ciências Humanas da PUC-Rio. Aprovada pela Comissão Examinadora abaixo assinada.
\end{abstract}

Prof. Mario de França Miranda

Orientador

Departamento de Teologia - PUC-Rio

Prof ${ }^{a}$. Ana Maria Tepedino

Departamento de Teologia - PUC-Rio

Prof. Paulo Cezar Costa

Departamento de Teologia - PUC-Rio

Prof. Vitor Galdino Feller

Instituto Teológico de Santa Catarina

Prof. Paulo Fernando Carneiro de Andrade

Coordenador Setorial de Pós-Graduação e Pesquisa do Centro

De Teologia e Ciências Humanas - PUC-Rio

Rio de Janeiro, 28 de fevereiro de 2007 
Todos os direitos reservados. É proibida a reprodução total ou parcial do trabalho sem autorização da universidade, do autor e do orientador.

Antonio José Afonso da Costa

Concluiu o curso Eclesiástico de Filosofia na Escola Teológica da Congregação Beneditina do Brasil em 1994. Graduou-se em Teologia no Instituto Superior de Teologia da Arquidiocese do Rio de Janeiro em 1998. Concluiu o Mestrado em Teologia na PUC-Rio em 2002. Desde 2005 é professor de Teologia da Faculdade de São Bento do Rio de Janeiro.

Ficha Catalográfica

Costa, Antonio José Afonso da

Justificação e batismo na obra de Wolfhart Pannenberg: perspectivas para 0 diálogo ecumênico / Antonio José Afonso da Costa ; orientador: Mario de França Miranda. - 2007.

216 f. ; $30 \mathrm{~cm}$

Tese (Doutorado em Teologia)-Pontifícia Universidade Católica do Rio de Janeiro, Rio de Janeiro, 2007.

Inclui bibliografia

1. Teologia - Teses. 2. Justificação. 3. Fé. 4. Batismo. 5. Igreja. 6. Sacramento. 7. Graça. 8. Ecumenismo. I. Miranda, Mario de França. II. Pontifícia Universidade Católica do Rio de Janeiro. Departamento de Teologia. III. Título. 


\section{AGRADECIMENTOS}

PUC-Rio, pela bolsa de estudos que possibilitou a conclusão dessa pesquisa.

Pe. Mario de França Miranda, pelo exemplo de vivência da vocação à pesquisa teológica.

Aos amigos que colaboraram, de diversos modos, para a conclusão desse trabalho. 


\section{RESUMO}

Costa, Antonio José Afonso; Miranda, Mario de França (orientador). Justificação e batismo na obra de Wofhart Pannemberg: perspectivas para 0 diálogo ecumênico. Rio de Janeiro, 2007. 216p. Tese.de Doutorado - Departamento de Teologia, Pontifícia Universidade Católica do Rio de Janeiro

A tese tem por objeto o nexo entre a doutrina da justificação e o sacramento do batismo na obra de Wolfhart Pannenberg e suas repercussões para o diálogo ecumênico. A doutrina da justificação representa um dos testemunhos do Novo Testamento a respeito da salvação oferecida por Deus em Cristo e sua importância como critério para o discurso e a prática eclesial foi evidenciada pela reforma luterana. Contudo, a teologia católica e aquela protestante desenvolveram concepções distintas da obra da justificação, o que foi motivo de incompreensões e condenações recíprocas. Wolfhart Pannenberg, teólogo luterano do século XX, apresenta a doutrina da justificação a partir do diálogo entre as confissões. Sem esconder os contrastes que existem entre a posição católica e a luterana, ele procura compreender as posições de ambas no quadro mais amplo de uma renovada pesquisa bíblica e a partir da intencionalidade dos enunciados doutrinais. Assim, percebe-se claramente que os desdobramentos distintos que essa doutrina assumiu no interior das duas teologias não são motivo de condenações ou separação das igrejas. Elemento chave para a compreensão da doutrina da justificação em W. Pannenberg é o modo como ele a entende em referência ao sacramento do batismo. A presente pesquisa deseja evidenciar essa relação como corolário do projeto sistemático de Pannenberg, mediado pelo seu modo de entender a dinâmica da fé, bem como demonstrar suas fecundas conseqüências para o diálogo ecumênico e a prática das igrejas. Para isso, explicitará o conceito de fé na obra do autor, demonstrando, então, o que significa para ele a expressão 'justiça da fé' e de que modo essa se coliga com a união do fiel com Cristo, sacramentalmente realizada pelo batismo. Por fim, evidenciará que a valorização do elemento sacramental no discurso sobre a justificação, por parte desse autor luterano, corrige unilateralidades que se sedimentaram na tradição teológica protestante e oferece novas perspectivas para repensar algumas práticas pastorais e ecumênicas da igreja católica.

\section{PALAVRAS-CHAVE:}

Justificação, fé, batismo, igreja, sacramento, graça, ecumenismo. 


\section{ABSTRACT}

Costa, Antonio José Afonso; Miranda, Mario de França (Advisor). Justification and Baptism on the work of Wolfhart Pannenberg. Perspectives on the ecumenical dialogue. Rio de Janeiro, 2007. 216p. Doc. Thesis. Departamento de Teologia, Pontifícia Universidade Católica do Rio de Janeiro.

The doctrine of the justification represents one of the testimonies of the New Testament regarding the salvation which God has offered in Christ. Its importance for the ecclesiastical speech and practice was evidenced in the Lutheran Reformation. However, catholic theology and the protestant one have developed distinct conceptions concerning the theology of justification, something that caused reciprocal misunderstanding and condemnations. Wolfhart Pannenberg, XX century lutheran theologian, presents the doctrine of the justification from the dialogue between those Confessions. Without hiding the contrasts that exist between catholic and lutheran perspectives, he searches the comprehension of both positions through a deep biblical research and from the intention of the doctrinal statements. Thus, one perceives clearly the distinct unfoldings that this doctrine assumed within both theologies should not constitute a reason for condemnations or separation among the churches. The key element for the understanding of the doctrine of the justification in W. Pannenberg's is the way he understands it in reference to the sacrament of the baptism. The goal of the present research is to evidence this relation as a corollary of Pannenberg's systematic project, through his way of understanding the dynamics of the faith, as well as demonstrating its fruitful consequences to the ecumenical dialogue and the practice of the churches. We intend to convey the concept of faith in the author's work as well as demonstrate what he means for the expression "justice of the faith" and the way it connects to the union of the faithful with Christ, sacramentally carried on through baptism. Finally, we are to evidence that the valuation of the sacramental element in the speech on the justification, on the part of this lutheran author, corrects those unilateral positions which had been settled in the protestant theological tradition and offer new perspectives to rethink some ecumenical and pastoral actions of the Catholic Church.

\section{KEY-WORDS:}

Justification, faith, baptism, church, sacrament, favour, ecumenism. 


\section{SUMÁRIO}

$\begin{array}{ll}\text { 1. Introdução } & 10\end{array}$

2. O projeto sistemático de W. Pannenberg e o ecumenismo:

A doutrina da justificação a partir do diálogo 14

2.1. O projeto sistemático de W. Pannenberg 14

2.2. Revelação como história e sua demonstrabilidade 15

2.3. Cristologia e Antropologia 23

2.4. Igreja e Ecumenismo 28

3. A Declaração Conjunta Sobre a Doutrina da Justificação 32

3.1. Percurso histórico do diálogo católico-luterano 32

3.1.1. Metodologia teológica e diálogo ecumênico 33

3.1.2. A categoria de 'consenso diferenciado' como chave metodológica da DC 38

3.2. O itinerário do diálogo católico-luterano 41

3.2.1. O diálogo a nível internacional 41

3.2.2. O diálogo a nível regional, nos Estados Unidos e na Alemanha 46

3.3. A Declaração Conjunta: expressão da fé a partir do diálogo 54

3.3.1. O consenso 56

3.3.2. Desdobramentos doutrinais distintos mas compatíveis com o consenso 59

3.4. Parecer de W. Pannenberg sobre a Declaração Conjunta 64

4. Um nexo fundamental para o diálogo ecumênico:

justificação e batismo

69

4.1. Uma correlação fundamental: fé e justificação 69

4.2. O conceito de fé em Pannenberg 70

4.2.1. Fé e conhecimento histórico $\quad 74$

4.2.2. Ato de fé e comunidade de fé $\quad 82$

4.2.3. Ato de fé e estrutura essencial do ser humano 92

4.3. O ser humano à imagem e semelhança de Deus 95

4.3.1. Pecado e afastamento de Deus 106

$\begin{array}{ll}\text { 4.3.2. A reconciliação com Deus em Cristo, fundamento da } & 111 \\ \text { Justificação } & 114\end{array}$

4.3.2.1. Reconciliação e expiação 114

4.3.2.2. Existência reconciliada e filiação divina 122

4.4. Linguagem da justificação e salvação cristã 126 
5. Um nexo fundamental para o diálogo ecumênico: fé, batismo e Justificação

5.1. Batismo como sacramento 140

5.1.1. A idéia bíblica de mistério e o conceito teológico de sacramento 143

5.1.2. A instituição divina dos sacramentos e o caso específico do batismo

5.2. Morte de Cristo, batismo e seus efeitos na vida do cristão 151

5.3. O batismo, sacramento da fé 161

5.4. Batismo e justificação 166

5.5. Avaliação de algumas controvérsias do tempo da Reforma a partir da relação entre justificação e batismo em W. Pannenberg

6. Avaliação da apresentação da doutrina da justificação em

W. Pannenberg e novas perspectivas para o diálogo ecumênico

180

6.1. Fundamento objetivo da fé, subjetivismo moderno e teologia evangélica

6.2. Afinidades com a teologia católica e provocações à pastoral e à prática ecumênica

8. Referências Bibliográficas 


\section{LISTA DE ABREVIATURAS}

CA Confissão de Augsburgo

CDC Código de Direito Canônico

DC Declaração Conjunta sobre a Doutrina da Justificação

DH Denzinger-Hünermann

EO Enchiridion Oecumenicum

LG Lumen Gentium

PO Presbyterorum Ordinis

UR Unitatis Redintegratio 